\title{
The Status and Role of Tea in British Culture and Daily Life against the Background of British Empire Expansion from 1600 to 1900
}

\author{
Aoran Zhang \\ School of Foreign Languages and Cultures, Nanjing Normal University, Jiangsu Province, China \\ 3330215808@qq.com
}

\begin{abstract}
Tea, as a world beverage, has been loved by people in many countries and regions since ancient times. Throughout history, tea played the role of "cultural messenger", allowing Westerners, especially British, to understand the mysterious oriental civilization through diet and meanwhile integrate tea culture into their own. As a necessity of daily life, tea closely connects people all over the world in the process of its production, sales and consumption, and creates extraordinary cultural and social values in history. In Britain, tea is an indispensable part of British daily life, which greatly impacts British culture and society. In this paper, the author explores the origin, development of tea in British culture and daily life in the period from 1600 to 1900, analyzing four main impacts including economy and trade, social activities, diet, and literature.
\end{abstract}

Keywords: Tea, Tea culture and history, Britain, Influence of tea.

\section{Introduction}

Nowadays, many countries drink tea in the world, but few countries are closely related to tea. Tea originated in China. With the in-depth development of Sino-Western trade, tea gradually spread to Europe and finally crossed the English Channel to Britain. Therefore, Britain has an indissoluble bond with tea. With only a few hundred years of history, tea has become Britain's "national beverage" and afternoon tea has become one of the representatives of British culture. Tea is not only the favorite drink of most British people, but also has a profound impact on British people's daily life and British culture.

\section{Origin and Development of British Tea}

British tea was first introduced from the Netherlands. Although there is no definite year, most scholars believe that the Dutch imported tea into Britain from the early to the middle of the 17 th century. In 1657 , the first tea merchant appeared in England. In 1658, the earliest advertisement for selling tea was published in Britain. In that period, tea was highly praised by many doctors and became popular with its medicinal efficacy in the market (Ma, 2010).

At first, its taste was not loved by the local people. Until 1662, Princess Catherine of Portugal set off a "tea drinking fever" among the royal nobles. Her love of tea soon made tea come into fashion in Britain. Since then, tea has changed from medicine to beverage in Britain and has become popular for its elegance in the upper class society (Ma, 2010). Before the era of George I, tea was still a rare and expensive thing prevailing in the upper class. Later, due to the decline of tea tax and the reduction of tea price, the consumption of tea increased 10 times in the early 18th century, and the total annual consumption reached almost 3 million pounds. Tea thus entered more ordinary families. In the middle of the 18th century, the sales of tea exceeded that of beer. From the end of the 18 th century to the beginning of the 19th century, drinking tea has been extremely popular in Britain. Tea has become the "national beverage" in Britain (Zou, 1992).

In this short history of several hundred years, tea has had a far-reaching impact. It has changed from a miracle drug in the East to a favorite drink in Britain, which is closely connected with Britain's economy, trade, social activities, dietary structure and literary works.

\section{The Influence of Tea on British Culture and Daily Life}

\subsection{The Influence of Tea on British Economy and Trade}

In the last 20 years of the 17th century, Britain completed the glorious bourgeois revolution and officially entered the capitalist era with social and political stability and economic prosperity, which provided a good social environment for commercial development.

After the Anglo-Dutch War, Britain enjoyed its unchallenged maritime hegemony. In this case, British East India Company (BEIC) continued to grow. As Britain does not produce tea, the supply of tea almost depends on imports. At the beginning of the 17th century, tea trade was one of the most important trade items of BEIC. The European trade was successfully transformed into the Asian import business model. BEIC adopted the exclusive franchise model, completely controlled the tea trade with China and monopolized China's tea trade for more than 200 years. The British government extracted high tea taxes from the tea trade. In the early 19th century, $10 \%$ of the British government's total tax revenue came from tea tax (Jia, 2008). The long-term high tea tax has led to the continuous increase in the price of tea, which made the ordinary people unable to buy and drink tea at will. Therefore, tea smuggling was prevalent. A large number of smuggled tea were transported to the South Bank of Britain by foreign ships, and the adulteration of tea was very active. Under this pressure, the British government had to reduce the rate of tea tax. Since then, smuggling has been eliminated. The demand for tea from formal channels has surged and the official 
income has soared. The annual revenue of tea tax was about 7 million pounds (Chen, 1984)

Therefore, under the influence of the tea monopoly trade of BEIC in the early period and the reduction of tea tax in the later period, Britain not only explored a new model of capitalist monopoly trade, but also greatly increased national income. In the expansion of tea trade, Britain's national strength was constantly strengthened.

\subsection{The Influence of Tea on British Social Activities}

The spirit of British tea is different from the Chinese one. The latter pays attention to "taste", while the former focuses on social functions. The British one is more dynamic (Cheng, 2004). After Princess Catherine married King Charles II, drinking tea was advocated in British palace. Later, Mary II and Queen Anne joined in the tea group. They held tea parties when they had nothing to do. Upper class such as nobles and rich families followed suit, and family tea parties became the most fashionable social etiquette in the upper class, which generated afternoon tea (Gu, 1999). As a symbol of fashion and an introduction to social networking, afternoon tea is the best form for British people to entertain friends and start salons, which has evolved many rituals and etiquette.

Then, tea became popular in London cafes and other places. Gentlemen drink tea in cafes, do business, socialize and talk about politics, while noble women drink tea at home and chat with their friends (Ma, 2010). At that time, the hostesses of noble families believed that it was a glorious thing to have the opportunity to make and serve tea in front of guests. The series of procedures before drinking tea were so beautiful and charming. Therefore, they liked to invite friends home to drink tea and express themselves. In addition, friends would often invite each other back, which was a decent social way. Later, the expansion of operation mode of those cafes such as retailing a large number of dry tea and the emergence of the first tea store in which women can enter and leave freely made afternoon tea party appeared in more ordinary families. In the afternoon, housewives invited several friends to spend a relaxing and happy time together when they were free (Hao, 1998). In the 18th century, apart from family tea, tea gardens appeared in Britain. Tea gardens are a pure field of public life, where people meet friends, read newspapers, hold parties, discuss problems or exchange public opinions. At the end of the 18th century, the British would drink tea in the open air in public gardens (Ma, 2010).

Places for tea drinking developed from the inner court of the noble palace and official residence to cafes, then to ordinary families, and finally to public places such as tea gardens. In people's social activities, drinking tea has become an indispensable part.

\subsection{The Influence of Tea on British Diet}

Before tea became a national drink in Britain, the British diet was basically hot food and cold drink. Milk was their traditional drink, while the popularity of tea has enabled the British to integrate their national milk and bitter tea into a sweet beverage, which is rich in protein, fat, carbohydrates and vitamins. Therefore, tea has gradually become a daily necessity with strong fragrance and rich nutrition, a supplementary beverage for daily food. This integration completed the practicability and localization of tea (Cheng, 2004). In addition, the formation of the custom of drinking tea cured the alcohol drinking habit in Britain after the middle ages and strengthened the national physique. In a short essay in 1699, the British writer Joha Ovington wrote: "drinking tea has magical curative effect, which can sober people's mind and make drunkards return to reason (Zou, 1992)."

Tea has gradually changed from a luxury to a necessity of life, enriching the British diet. It can not only supplement the nutrition of the body to a certain extent, but also warm the body and activate thinking.

\subsection{The Influence of Tea on British Literature}

In 1662, the first English tea poem On Tea was born. It is one of the poems of Edmund Waller, an English poet and politician. This poem expresses the praise of tea and the blessing to Queen Catherine. Later, British poet laureate Taylor and other writers Duncan Bell and Alexander Pope wrote poems with tea as the theme. Tea not only inspires poets, but also records the history of tea culture in the field of literature (Wang, 2016). Besides poets, tea is beloved by English novelists. In Austen's Pride and Prejudice, the protagonist will have a very formal tea party after each dinner. If the tea parties in Austen's novels are mostly aristocratic ones, Dickens's novels show the impact of tea on the life of ordinary people. A group of people get together, drink six pence a cup of tea and discuss the wonders of daily life. For them, the function of tea is to satisfy hunger or relieve fatigue. Through different descriptions of the tea party, the writer shows the different lives of people with different social status (Kang, 2017).

Although Britain has only a few hundred years of tea drinking history, tea has gradually integrated into British culture. British literary works have also drawn a lot of inspiration from tea, and tea has become an indispensable part of many artistic works.

\section{Conclusion}

Tea was first introduced into Britain as a medicine, and finally developed into a British "national beverage" for everyone to drink. At the beginning, it was only popular among palaces and noble people. Later, with the development of tea, it was widely spread among ordinary families. The places for drinking tea change from family to public garden, which represents the expansion of tea culture. If you say YES to a tea party invitation, the whole day would go. Whether it is breakfast tea or afternoon tea, tea time has been established in British daily life.

The evolution of tea culture is inseparable from British life. The origin and development of tea culture affect all aspects of British culture. Through the tea, we can see how a country's economy, trade, diet, literature, art, and life develop and change. Thus, tea is not only a drink, but also a work of art and a cultural history. 


\section{References}

[1] Chen Chuan. The General History of Tea. China Agricultural Press, Beijing, CHN. 1984: 440.

[2] Cheng Cuiying. The Formation, Characteristics and Influence of British Black Tea Culture. Dietetic Culture Research. 2004(03): 84.

[3] Cheng Cuiying. The Formation, Characteristics and Influence of British Black Tea Culture. Dietetic Culture Research. 2004(03): 85.

[4] Gu Zhenfeng. Light and Shadow of British Black Tea Culture. Agricultural Archaeology. 1999(04): 304.

[5] Hao Saili. British Tea Drinking Custom. China Tea. 1998(06):42.

[6] Jia Wen. British Tea Culture and Its Influence. MA Thesis, Nanjing Normal University, 2008: 53

[7] Ma Xiaoli. A Study of British Tea Culture from a Multi-dimensional Perspective. Zhejiang University Press, Hangzhou, CHN. 2010: 13-15.

[8] Ma Xiaoli. A Study of British Tea Culture from a Multi-dimensional Perspective. Zhejiang University Press, Hangzhou, CHN. 2010: 27.

[9] Ma Xiaoli. A Study of British Tea Culture from a Multi-dimensional Perspective. Zhejiang University Press, Hangzhou, CHN. 2010: 44.

[10] Ma Xiaoli. A Study of British Tea Culture from a Multi-dimensional Perspective. Zhejiang University Press, Hangzhou, CHN. 2010:67.

[11] Wang Pengjuan. Interpretation of Tea Culture in English Literary Works. Tea in Fujian. 2016(07): 379-380.

[12] Zou Hu. Historical Data of Early Tea Drinking in Britain-When did the British Start Drinking Tea. Agricultural Archaeology. 1992(02): 242.

[13] Zou Hu. Historical Data of Early Tea Drinking in Britain-When did the British Start Drinking Tea. Agricultural Archaeology. 1992(02): 243. 